Document downloaded from:

http://hdl.handle.net/10251/28830

This paper must be cited as:

García Breijo, FJ.; Reig Armiñana, J.; Aguado, M.; Martinez-sanchez, JJ.; Franco, JA.; Vicente, MJ. (2011). Morphology, anatomy and germination response of heteromorphic achenes of Anthemis chrysantha J. Gay (Asteraceae), a critically endangered species.. SEED SCIENCE RESEARCH. 21(4):283-294. doi:10.1017/S0960258511000183.

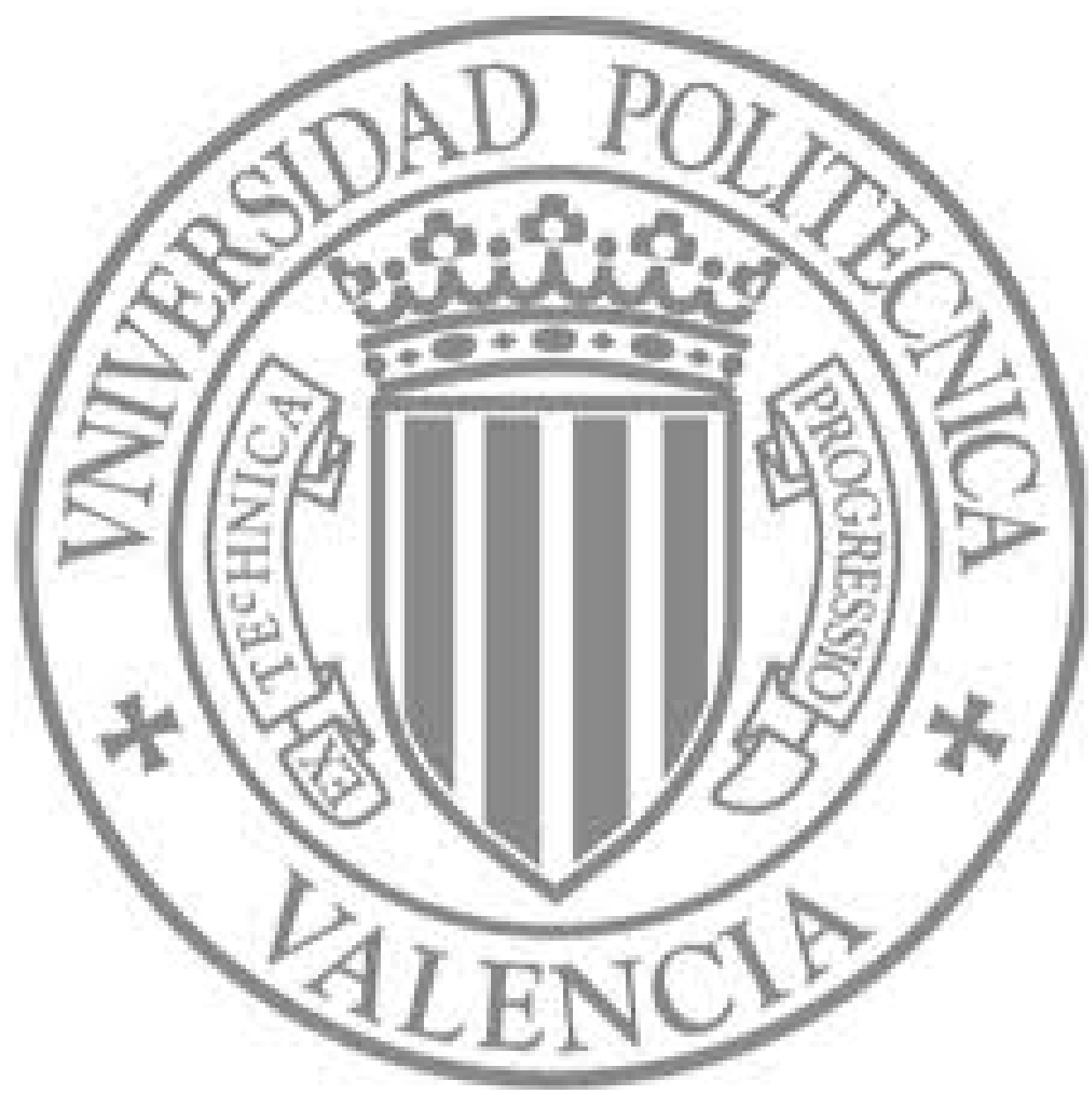

The final publication is available at

http://dx.doi.org/10.1017/S0960258511000183

Copyright Cambridge University Press 


\title{
Morphology, anatomy and germination response of heteromorphic achenes of Anthemis chrysantha J. Gay (Asteraceae), a critically endangered species
}

\author{
Mayra Aguado ${ }^{1}$, Juan J. Martínez-Sánchez ${ }^{1 *}$, José Reig-Armiñana ${ }^{2}$, Francisco J. García-Breijo ${ }^{2,3}$, \\ José A. Franco ${ }^{1}$ and María J. Vicente ${ }^{1}$ \\ ${ }^{1}$ Departamento de Producción Vegetal, Instituto de Biotecnología Vegetal, Universidad Politécnica de Cartagena, \\ Paseo Alfonso XIII, 48, 30203 Cartagena, Spain; 'Laboratorio 'Julio Iranzo' de Anatomía Vegetal, Jardín Botánico \\ de la Universidad de Valencia, C/ Quart, 80, 46008 Valencia, Spain; ${ }^{3}$ Departamento de Ecosistemas \\ Agroforestales, Universidad Politécnica de Valencia, Camino de Vera s/n. 46022, Valencia, Spain
}

\begin{abstract}
This study demonstrates that Anthemis chrysantha, a 'Critically Endangered' annual plant, produces two morphs of achenes: white and dark achenes, which differ in size, mass, anatomy and germination behaviour. Fresh white achenes germinated at all temperatures assayed from 10 to $25^{\circ} \mathrm{C}$ in both continuous darkness and 12-h photoperiod, ranging between $24 \%$ at $25^{\circ} \mathrm{C}$ in darkness and $89 \%$ at $12 / 20^{\circ} \mathrm{C}$ in light, whereas fresh dark achenes did not germinate under any temperature or light conditions. To identify differences in dormancy type between the two morphs, germination of dry-stored achenes, and achenes stratified at 5 or $25^{\circ} \mathrm{C}$ for 2 months were tested in both darkness and light at 5,15 and $12 / 20^{\circ} \mathrm{C}$ for drystored and warm-stratified $\left(25^{\circ} \mathrm{C}\right)$ achenes; and at 15 , 25 and $12 / 20^{\circ} \mathrm{C}$ for cold-stratified $\left(5^{\circ} \mathrm{C}\right)$ achenes. Of the white achenes, 90\% germinated during the cold stratification period. In general, dry storage and warm stratification did not increase germination compared to fresh achenes. However, dark achenes did not germinate under any conditions. Dark achene dormancy was only broken by mechanical scarification or by excising the embryo (germination reached $71 \%$ ). An anatomical study showed that the mesocarp of dark achenes had no intercellular spaces and was much thicker and stronger than that of white achenes, making the entry of water difficult, and also preventing germination by mechanical restriction. This study demonstrated that dormancy in the dark achenes is likely caused by the thickness of their pericarp,
\end{abstract}

${ }^{*}$ Correspondence

Fax: + 34968325433

Email: juan.martinez@upct.es physically impeding germination and hampering imbibition of water.

Keywords: Anthemis, endangered species, heteromorphic fruits, pericarp structure, seed dormancy, seed germination

\section{Introduction}

The morphology and physiological behaviour of seeds are important features for understanding the pattern of seasonal and spatial distributions of species (Silvertown and Doust, 1993; Imbert, 2002). Many species of Asteraceae are known for producing two or more different morphs of achenes within a single plant (Imbert, 2002; Brändel, 2004), which is generally associated with adaptation to unstable environments (Harper, 1977; Venable, 1985). Seed polymorphism can affect characteristics such as dispersal capacity, seed dormancy, predation, germinability and seedling competition (Harper, 1977; Imbert et al., 1996; Brändel, 2004).

According to Nikolaeva (1977), in endogenous dormancy some characteristic of the embryo prevents germination, whereas in exogenous dormancy, some characteristic of structures covering the embryo prevents germination. This author defined physical exogenous dormancy as an impermeability to water of the seed (fruit) coats. Most types of dormancy can be broken by warm and/or cold stratification, but not physical exogenous dormancy.

There have been studies on the morphology of the capitulum and the fruit in order to establish phylogenetic classifications within the Asteraceae (Chehregani and Mahanfar, 2007; Kreitschitz and 
Vallés, 2007), and some have described relationships between fruit morphology and germination capacity (Porras and Muñoz, 2000; Imbert, 2002; Brändel, 2004; Sun et al., 2009), but very few have addressed germination in the genus Anthemis (Rashid et al., 2007). Anthemis L. is the second largest genus within the Asteraceae (tribe Anthemidae), with more than 210 species in the Mediterranean region, south-west Asia and eastern Africa (Oberprieler, 2001); about 62 species are distributed in Europe and 14 in the Iberian Peninsula. One of these species is A. chrysantha J. Gay, an annual plant endemic to North Africa and the south-east of the Iberian Peninsula. It is only found on the Algerian coast and, in Europe, only on the coast of Cartagena (Murcia, south-eastern Spain). In Cartagena, four populations had been known, but since the late 1990s only two have remained, occupying an area of less than 2 ha. A. chrysantha grows in therophytic meadows affected by the sea winds, between halophytic thyme bushes. It was first classified as Endangered and later as Critically Endangered (Sánchez et al., 2004) according to the International Union for Conservation of Nature categories. It is currently protected by a regional law of Murcia (BORM, 2003).

Despite the degree of threat to this species, there are few references to its distribution and the plant communities in which it appears (Sánchez et al., 2004), and no reports on its biology and ecology. In general, in order to establish appropriate measures for the conservation of a species, it is necessary to determine its reproductive biology and ecology. One of the most important aspects of the reproductive biology of a species, especially in arid and unpredictable environments, is the response of seed germination (Gutterman, 1993). Since the existence of heteromorphic achenes is not mentioned in the botanical description of $A$. chrysantha (Tutin et al., 1980), the aims of the present study were to: (1) explore morphological and anatomical variability in achenes; (2) identify possible differences in dormancy and germination behaviour; and (3) determine possible adaptive advantages of this variation in A. chrysantha achenes.

\section{Materials and methods}

\section{Plant material}

The capitula (fruit heads hereafter) of $A$. chrysantha (with yellow flowers on a rather convex disc of $12-25 \mathrm{~mm}$ in diameter), have peduncles up to $6 \mathrm{~cm}$ in length. The receptacle is hemispherical to oblongovoid, and rounded at the apex (Tutin et al., 1980). Each fruit head contains about 100-130 achenes, with receptacular bracts between them, arranged in several rows (7-12) on the disc. Achenes are obconical, generally shorter than $2 \mathrm{~mm}$, with ten granular ribs and a denticulate rim or sometimes a short crenulate auricle (pappus). Under a stereoscopic microscope two principal morphs of achenes are distinguishable within one fruit head: the rows of the upper section containing elongated, almost white achenes (white achenes hereafter), while the achenes of the basal rows are brown-black (dark achenes hereafter) and harder than white achenes. Finally, the last basal line is composed of achenes from ligules (only 8-10 per fruit head), which are similar to white achenes but frequently are empty, and were not studied in this work. The proportion of white and dark achenes in a fruit head is about 70 and $30 \%$, respectively. The percentage of empty white and dark achenes is very variable from one fruit head to another, but the average in the dark achenes is always lower than in white achenes (about 10 and 24\%, respectively). A representative sample of freshly matured achenes was collected from La Azohía (Cartagena, Murcia; $37^{\circ} 33^{\prime} 8^{\prime \prime} \mathrm{N}$; $1^{\circ} 10^{\prime} 22^{\prime \prime} \mathrm{W}$; altitude $30 \mathrm{~m}$ ). This area has a semi-arid Mediterranean climate characterized by irregular rainfall and a harsh, dry summer period. Annual mean precipitation is around $300 \mathrm{~mm}$, and mean annual temperature is $17^{\circ} \mathrm{C}$. August is the warmest month, with an average temperature of $24.9^{\circ} \mathrm{C}$ and a maximum of $42^{\circ} \mathrm{C}$. The coldest month is January, with an average temperature of $10.6^{\circ} \mathrm{C}$ and the minimum always $>0^{\circ} \mathrm{C}$. Central fruit heads at similar states of maturation were harvested in July 2009 from $>400$ plants. Achenes were separated according to the white or dark type using a stereoscopic microscope (Olympus SZ61), and stored for 6-7d at room temperature before germination studies.

\section{Morphological characterization of achenes and embryos}

Using a stereoscopic microscope with a micrometer, the length, width and pappus length were determined for 50 randomly selected achenes of each type. After measuring of the achenes, the pericarp was removed to determine the length and width of the embryos. Similarly, to estimate the mass of the achenes and embryos, 50 achenes of each type were weighed using a Mettler Toledo XP56 electronic microbalance (with $0.001 \mathrm{mg}$ precision).

\section{Achene germination tests}

\section{Effect of temperature and light on the germination of fresh achenes}

To determine the influence of light and temperature on achene germination, 100-achene lots of each type were incubated at each of the following constant temperature regimes: $10,15,20$ and $25^{\circ} \mathrm{C}$, and an alternating 
temperature regime at $12^{\circ} \mathrm{C}$ in darkness and $20^{\circ} \mathrm{C}$ in light. Each 100-achene lot was distributed into four samples of 25 achenes. Each sample was incubated in a 9-cm-diameter Petri dish, on a double layer of filter paper moistened with $4 \mathrm{ml}$ of distilled water, in germination chambers (Sanyo MLR-351H, Osaka, Japan) with a temperature and light control system $\left( \pm 0.1^{\circ} \mathrm{C}\right.$, cool white fluorescent light of $\left.20,000 \mathrm{~lx}\right)$. Achenes were tested for germination in both continuous darkness and light at each temperature regime. Dark treatments were obtained by wrapping Petri dishes in a double layer of aluminium foil. Achenes were checked every $2-3 d$, and radicle protrusion was the criterion for successful germination. Achenes incubated in darkness were checked in a dark room using a stereoscopic microscope with light source (lamp type EKE $21 \mathrm{~V} / 150 \mathrm{~W}$ halogen; illuminance intensity $5.7 \mathrm{Mlx}$ ) covered by a double layer of cellophane (blue and green) acting as a filter. These layers reduce considerably the number of red light photons, but do not exclude them entirely. Thus, data regarding photosensitivity should be treated with caution. The experiments in both light and darkness were terminated after $37 \mathrm{~d}$.

\section{Effects of stratification and dry storage on achene germination}

Simultaneously, each achene type was subjected to a wet-cold stratification treatment at $5^{\circ} \mathrm{C}$ or a wetwarm stratification at $25^{\circ} \mathrm{C}$ for 2 months in darkness. One achene lot was stored dry at room temperature during the same period. Then, four samples of 25 dark achenes each from the cold-stratification treatment were incubated at 15,25 and $12 / 20^{\circ} \mathrm{C}$; white achenes from the cold stratification could not be incubated at these temperatures due to the high germination during the stratification period (c. 90\%). Both the warmstratified and the dry-stored achenes were incubated at 5,15 and $12 / 20^{\circ} \mathrm{C}$. All treatments were tested for germination in both continuous darkness and light. Achene germination was checked every $2-3 \mathrm{~d}$ for $37 \mathrm{~d}$. At the end of the germination period, the germination percentage and the mean time to germination (MTG) were calculated for all treatments. The latter was determined using the following formula (Brenchley and Probert, 1998): MTG $=\left(\Sigma_{i} n_{i} \times d_{i}\right) / N$; where $n$ is the number of achenes germinated at day $i, d$ is the incubation period in days, and $N$ is the total number of achenes germinated in the treatment.

\section{Role of pericarp on water absorption and embryo germination}

Four samples of 25 embryos (without pericarps) from each type of achene were incubated in the abovementioned germination chambers in light at 15, 20 and
$12 / 20^{\circ} \mathrm{C}$. Embryo germination was checked every $2-3 \mathrm{~d}$ for $37 \mathrm{~d}$. To determine if the hardness of the dark achene pericarp could affect embryo germination, four samples of 25 dark achenes with their fruit coats were scarified slightly at the basal end (radicle end) or at the apical end (cotyledon emergence point) and incubated in light at $12 / 20^{\circ} \mathrm{C}$ for $37 \mathrm{~d}$. At the end of the scarification tests, embryos from ungerminated achenes were checked for viability on the basis of embryo appearance, paying special attention to colour and turgidity (Copete et al., 2009). Those achenes that looked viable were tested further for viability using the tetrazolium test with a $1.0 \%(\mathrm{w} / \mathrm{v})$ solution. In order to determine if water entered through the achene pericarp and was absorbed by the embryos, five 20 -achene lots of each type were weighed. They were then maintained in 9-cm-diameter Petri dishes (one lot per dish), on a double layer of filter paper moistened with $4 \mathrm{ml}$ of distilled water, at room temperature for $36 \mathrm{~h}$. Then the lots of achenes were weighed again, the embryos were excised from the achenes and weighed too. Since preliminary results showed a very slow increase of fresh mass in dark achenes, two further experiments were conducted. First, 50 dark achenes were weighed individually (with $0.001 \mathrm{mg}$ precision), maintained in a tube with $0.5 \mathrm{ml}$ of distilled water at room temperature for $14 \mathrm{~d}$, and then weighed again. The embryos were excised from the achenes and were also weighed. Then, 30 achenes of each type (i.e. dark and white) were imbibed individually at room temperature for $7 \mathrm{~d}$, in a $50 \%$ aqueous solution of fuchsin basic-carbol to determine whether the solution penetrated to the embryos.

\section{Anatomical characterization of achenes}

Two lots of each achene type were studied using a scanning electron microscope (Hitachi S-3500N, Singapore) with backscattered electron detector, working in low vacuum mode $(70 \mathrm{~Pa})$. Conditions were accelerating voltage of $15 \mathrm{kV}$ and working distance of $15 \mathrm{~mm}$. Separately, two lots of each achene type were cut superficially to facilitate the subsequent process of infiltration. Some of the samples of each lot were fixed under vacuum with $2 \%$ glutaraldehyde, washed with $0.1 \mathrm{M}$ phosphate buffer $(\mathrm{pH} 7.4)$ and dehydrated in an ethanol series (50,70,96\%, followed by $2 \times 100 \%)$, and infiltrated by Histosec ${ }^{\circledR}$ paraffin (Merck, Darmstadt, Germany) at $56-58^{\circ} \mathrm{C}$. Isoamyl acetate was used as an intermediary solvent between the ethanol and the paraffin; the infiltration time was $60 \mathrm{~min}\left(\right.$ at $\left.60^{\circ} \mathrm{C}\right)$ and the blocks were cut into 8- $\mu \mathrm{m}$ sections with an Anglia Scientific microtome (Ontario, Canada). After removing the paraffin with xylene and subsequent tissue rehydration in an ethanol series, the samples were stained with safranin and fast green (Johansen, 1940). 
Other samples of each lot were included after fixation in Spurr resin (Spurr, 1969). Semi-thin sectioning $(1.5 \mu \mathrm{m})$ was done with a Sorvall MT 5000 Ultra Microtome (Girald-Dupont, Wilmington, Detroit, USA) with glass blades $\left(45^{\circ}\right)$ obtained from a special glass (Glass Strips $6.4 \mathrm{~mm}$ from Leica) in a knifemaker (Reichert-Jung, Wien, Austria). These samples were dyed with toluidine blue (Ruzin, 1999) at 1\%. To observe the preparations, an Olympus Provis AX-70 light field microscope (Capovani Brothers Inc., Scotia, New York, USA) was used, and pictures were taken with an Infinity 2 CCD digital camera (Lumenera Corp., Ottawa, Canada) and treated with image acquisition software 'Infinity Analyze' (Lumenera Corp.).

\section{Statistical analysis}

A multivariate analysis of variance (MANOVA) was used to evaluate the effects of the different assay treatments on each type of achene and embryo. Data were analysed with SPSS 13.0 software for Windows (SPSS Inc., Chicago, Illinois, USA). When significant main effects existed, differences were tested by Tukey's multiple comparison test at $95 \%$ confidence level. Percentage germination data were arcsine square-root transformed to meet the MANOVA requirements.

\section{Results}

\section{Morphological characterization of achenes and embryos}

Dark achenes had significantly greater length, width, mass and pappus length than white achenes.
However, embryos from the two types of achenes were only significantly different in width, with those of the dark achenes being wider (Table 1).

\section{Achene germination tests}

\section{Effect of temperature and light on the germination of fresh achenes}

There were significant differences for the three factors considered (achene type, temperature and light) and their interactions regarding achene germination $(P<0.05)$. Dark achenes occasionally reached $2-3 \%$ germination at 15 and $25^{\circ} \mathrm{C}$ in light but generally did not germinate. Thus, each type of achene was analysed separately. White achenes germinated in all treatments assayed, within a germination range of $24-89 \%$ (Fig. 1A). In the light at constant temperatures significant differences in germination were observed, ranging from $68 \%$ at $15^{\circ} \mathrm{C}$ to $51 \%$ at $10^{\circ} \mathrm{C}$ (Fig. $1 \mathrm{~A}$ ). The alternating regime of $12 / 20^{\circ} \mathrm{C}$ increased germination percentages significantly $(P=0.000)$, with a maximum of $89 \%$ (Fig. 1A). However, the MTG was not significantly different at $12 / 20^{\circ} \mathrm{C}$, as compared to 10,15 and $20^{\circ} \mathrm{C}$; germination was slowest at $25^{\circ} \mathrm{C}$ (Table 2). In darkness, the germination percentages at constant temperatures were significantly lower than those at $12 / 20^{\circ} \mathrm{C}$ (c. $\left.72 \% ; P=0.000\right)$. The lowest germination was also observed at $25^{\circ} \mathrm{C}$, although it was not significantly different from final germination at 20 and $15^{\circ} \mathrm{C}$ (Fig. 1A). As in light treatments, the highest MTG value in darkness was observed at $25^{\circ} \mathrm{C}$ (Table 2). In all temperature regimes, the achene germination in light was higher than in darkness (Fig. 1A). The MTG values obtained in darkness were significantly lower than in light, except at 20 and $25^{\circ} \mathrm{C}$ for which values were similar (Table 2 ).

Table 1. Morphometric characteristics and mass before and after imbibition of achene types and the corresponding embryos of Anthemis chrysantha

\begin{tabular}{|c|c|c|c|c|}
\hline \multirow[b]{2}{*}{ Morphometric characteristics } & \multicolumn{2}{|c|}{ Achenes } & \multicolumn{2}{|c|}{ Embryos } \\
\hline & White & Dark & White achenes & Dark achenes \\
\hline Pappus length (mm) & $0.36 \pm 0.02^{\mathrm{a}}$ & $0.50 \pm 0.03^{b}$ & & \\
\hline Length $(\mathrm{mm})$ & $1.33 \pm 0.02^{\mathrm{a}}$ & $1.39 \pm 0.02^{\mathrm{b}}$ & $1.09 \pm 0.01^{\mathrm{a}}$ & $1.09 \pm 0.01^{\mathrm{a}}$ \\
\hline Width (mm) & $0.68 \pm 0.01^{\mathrm{a}}$ & $0.75 \pm 0.02^{\mathrm{b}}$ & $0.48 \pm 0.01^{\mathrm{a}}$ & $0.50 \pm 0.01^{\mathrm{b}}$ \\
\hline Mass (mg) & $0.142 \pm 0.004^{\mathrm{a}}$ & $0.313 \pm 0.012^{\mathrm{bA}}$ & $0.110 \pm 0.002^{\mathrm{a}}$ & $0.116 \pm 0.003^{\mathrm{aA}}$ \\
\hline Mass after $14 \mathrm{~d}$ water imbibition (mg) & - & $0.349 \pm 0.013^{\mathrm{A}}$ & - & $0.154 \pm 0.004^{\mathrm{B}}$ \\
\hline Mass before $36 \mathrm{~h}$ water imbibition $(\mathrm{mg})^{*}$ & $3.480 \pm 0.086^{\mathrm{aA}}$ & $6.280 \pm 0.153^{\mathrm{bA}}$ & $2.504 \pm 0.071^{\mathrm{aA}}$ & $2.340 \pm 0.040^{\mathrm{aA}}$ \\
\hline Mass after $36 \mathrm{~h}$ water imbibition $(\mathrm{mg})^{*}$ & $7.540 \pm 0.774^{\mathrm{aB}}$ & $7.680 \pm 0.242^{\mathrm{aB}}$ & $4.300 \pm 0.138^{\mathrm{bB}}$ & $2.460 \pm 0.068^{\mathrm{aA}}$ \\
\hline
\end{tabular}

Means ( \pm standard error) within a row with different lowercase letters are significantly different from each other, within achene/embryo columns; means within a column with different uppercase letters are significantly different from each other (Tukey test; $P<0.05)$. Means are from 50 achenes or embryos $(n=50)$.

*Means from five 20 -achene lots $(n=5)$.

There are no data regarding white achenes/embryos mass after $14 \mathrm{~d}$ of water imbibition due to their germination after $2-3 \mathrm{~d}$. 


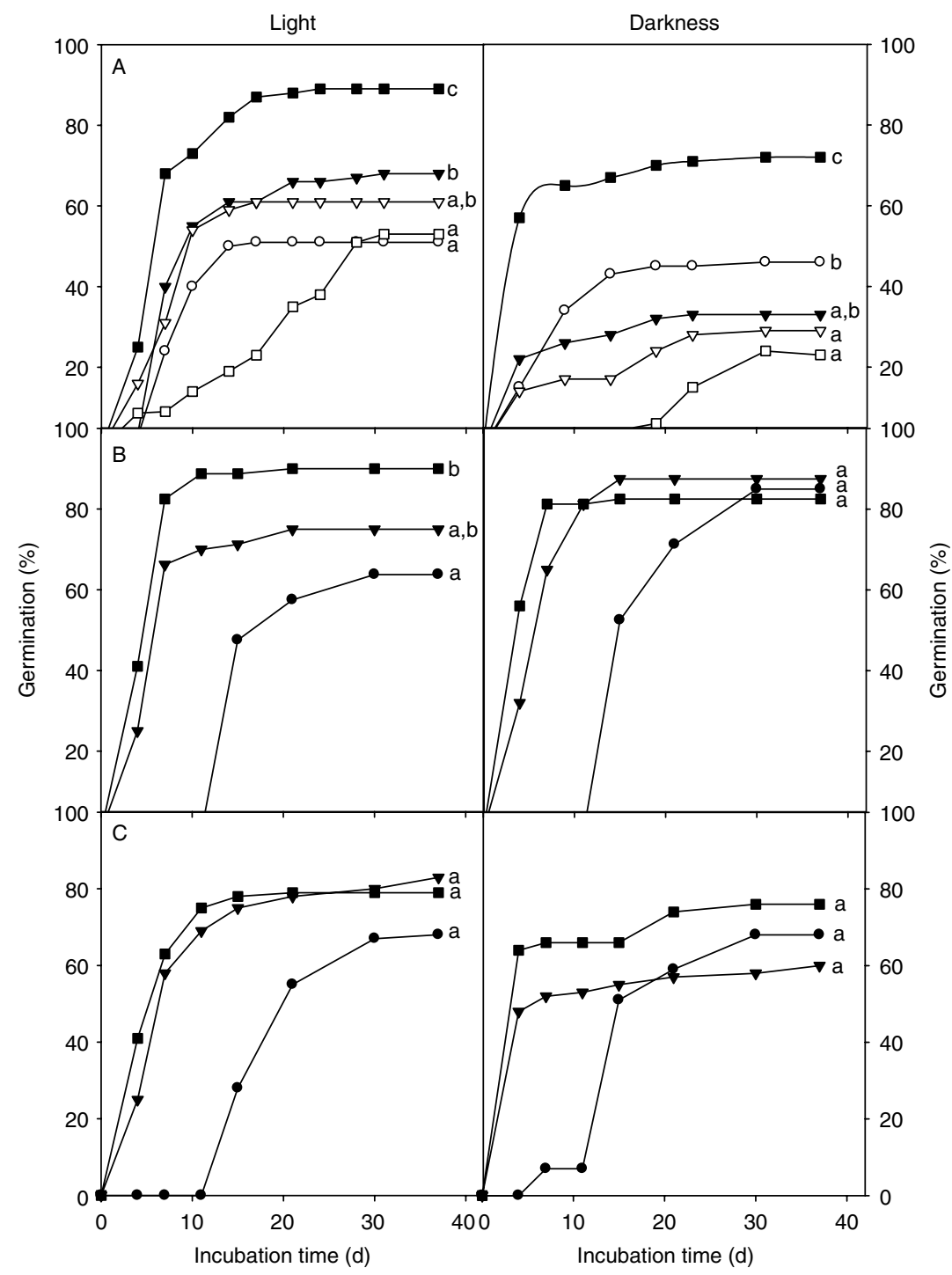

Figure 1. Germination of freshly matured white achenes (A), after wet-warm stratification (B) and after dry storage (C) of Anthemis chrysantha at $5^{\circ} \mathrm{C}$ (closed circles), $10^{\circ} \mathrm{C}$ (open circles), $15^{\circ} \mathrm{C}$ (closed triangles), $20^{\circ} \mathrm{C}$ (open triangles), $25^{\circ} \mathrm{C}$ (open squares) and $12 / 20^{\circ} \mathrm{C}$ (closed squares) under light (left) or darkness (right).

\section{Effects of stratification and dry storage on germination}

White achenes germinated to such a high percentage (c. $90 \%$ ) during the cold stratification that it was not possible to perform subsequent germination tests due to the insufficient remaining achenes. Dark achenes did not germinate during the cold stratification or in the subsequent germination testing at 15, 25 and $12 / 20^{\circ} \mathrm{C}$. Dark achenes did not germinate during warm stratification, while white achenes germinated to a low level $(8 \%)$. After warm stratification there were significant effects on the germination of the remaining white achenes due to the interaction between temperature and light $(P=0.036)$. White achenes germinated at high percentages without significant differences between light and darkness.
In light, the percentages ranged from $63 \%$ at $5^{\circ} \mathrm{C}$ to $90 \%$ at $12 / 20^{\circ} \mathrm{C}$, with significant differences $(P=0.010$; Fig. 1B). In darkness there were no significant differences between incubation temperature regimes, with germination values in the range of $82-87 \%$ (Fig. 1B). Both in light and darkness, the lowest MTG value was at $12 / 20^{\circ} \mathrm{C}$ and the highest at $5^{\circ} \mathrm{C}$ (Table 2). Warm-stratified dark achenes only germinated at 12 / $20^{\circ} \mathrm{C}$ in light, with a low final percentage of $c .5 \%$ (data not shown).

Final percentage germination of white achenes stored at dry room temperature ranged between 58 and $80 \%$ and there were significant differences at $15^{\circ} \mathrm{C}$ between light and darkness (Fig. 1C). The MTG values were also affected by light $(P=0.007)$ and temperature 
Table 2. Mean time to germination (MGT; days) of fresh, warm-stratified and dry-stored white achenes of $A$. chrysantha imbibed at different conditions of temperature and light

\begin{tabular}{|c|c|c|c|c|c|c|}
\hline \multirow[b]{2}{*}{ Temperature $\left({ }^{\circ} \mathrm{C}\right)$} & \multicolumn{2}{|c|}{ Fresh achenes } & \multicolumn{2}{|c|}{$\begin{array}{l}\text { Warm stratified } \\
\text { achenes }\end{array}$} & \multicolumn{2}{|c|}{$\begin{array}{l}\text { Dry-stored } \\
\text { achenes }\end{array}$} \\
\hline & Light & Darkness & Light & Darkness & Light & Darkness \\
\hline 5 & - & - & $17.39 \pm 0.25^{\mathrm{Ca}}$ & $18.74 \pm 0.32^{\mathrm{Cb}}$ & $20.38 \pm 1.29^{\mathrm{Ba}}$ & $16.99 \pm 0.58^{\mathrm{Ba}}$ \\
\hline 10 & $9.37 \pm 0.45^{\mathrm{Ab}}$ & $7.42 \pm 0.53^{\mathrm{ABa}}$ & - & - & - & - \\
\hline 15 & $9.22 \pm 0.91^{\mathrm{Ab}}$ & $6.35 \pm 0.26^{\mathrm{ABa}}$ & $6.72 \pm 0.33^{\mathrm{Ba}}$ & $6.94 \pm 0.13^{\mathrm{Ba}}$ & $8.29 \pm 0.50^{\mathrm{Ab}}$ & $5.78 \pm 0.69^{\mathrm{Aa}}$ \\
\hline 20 & $7.87 \pm 0.91^{\mathrm{Aa}}$ & $9.48 \pm 1.35^{\mathrm{Ba}}$ & - & - & - & - \\
\hline 25 & $18.72 \pm 1.43^{\mathrm{Ba}}$ & $16.58 \pm 1.22^{\mathrm{Ca}}$ & - & - & - & - \\
\hline $12 / 20$ & $7.28 \pm 0.72^{\mathrm{Ab}}$ & $5.35 \pm 0.19^{\mathrm{Aa}}$ & $5.26 \pm 0.48^{\mathrm{Aa}}$ & $4.57 \pm 0.32^{\mathrm{Aa}}$ & $6.54 \pm 0.12^{\mathrm{Aa}}$ & $6.41 \pm 1.08^{\mathrm{Aa}}$ \\
\hline$F$ & 24.856 & 27.245 & 327.744 & 779.569 & 87.919 & 59.896 \\
\hline$P$ & 0.000 & 0.000 & 0.000 & 0.087 & 0.000 & 0.000 \\
\hline
\end{tabular}

Means ( \pm standard error) within a column that have a different uppercase letter are significantly different from each other, and means within a row that have a different lowercase letter are significantly different from each other, within each achene treatment. $F$ and $P$ are the $F$-ratio value and the associated probability, respectively, obtained from the Tukey test at $95 \%$ confidence level.

$(P=0.000)$. Only at $15^{\circ} \mathrm{C}$ was germination faster in darkness than in light. Both in light and darkness the highest MTG value was at $5^{\circ} \mathrm{C}$ (Table 2). Dry-stored dark achenes did not germinate at any temperature. Compared to fresh achenes, only dry-stored white achenes incubated at $15^{\circ} \mathrm{C}$ (both in light and darkness), and warm-stratified white achenes incubated at the same temperature in darkness showed significantly higher germination percentages $(P=0.043$ and $P=0.001$, respectively, in light and darkness). On the other hand, nearly all dark achenes remained dormant and did not germinate at any temperature after 2 months of stratification treatments or dry storage.

\section{Role of pericarp on water absorption and embryo germination}

While dark achenes did not germinate during wholeachene germination experiments, excised embryos from dark achenes showed a high germination response of $57-71 \%$, with no significant differences among incubation temperatures. Excised embryos from white achenes also germinated similarly at all temperatures. However, their germination, which occurred in a range of $83-94 \%$, was always significantly higher than that of embryos from dark achenes $\left(P=0.002\right.$ at $15^{\circ} \mathrm{C}, P=0.002$ at $20^{\circ} \mathrm{C}$ and $P=0.011$ at $12 / 20^{\circ} \mathrm{C}$; Fig. 2). The MTG in embryos from white achenes was lower than that of embryos from dark achenes, except at $15^{\circ} \mathrm{C}$ (Table 3). The germination percentage of the dark achenes scarified at the basal end was $72 \pm 4.0 \%$, similar to that obtained when the embryos were completely excised, and significantly higher $(P=0.012)$ than that of achenes scarified at the apical end (39\%). However, when ungerminated achenes were checked for viability, $22 \%$ of them were non-viable.
After achene imbibition for $36 \mathrm{~h}$, embryos of white achenes increased their mass significantly, from 2.5 to $4.3 \mathrm{mg}(c .72 \% ; P=0.000$; Table 1$)$, while embryos from dark achenes showed no increase in mass. However, after $14 \mathrm{~d}$ of imbibition the average mass of embryos from dark achenes increased significantly $(P=0.000)$, but only by $33 \%$ (from 0.116 to $0.154 \mathrm{mg}$; Table 1 ). In addition, when the dark achenes were imbibed in the dye, the colour stain was seen in the embryo, mainly both at the radicle and at the opposite end, with the rest of the embryo not stained. However, embryos from white achenes were completely stained.

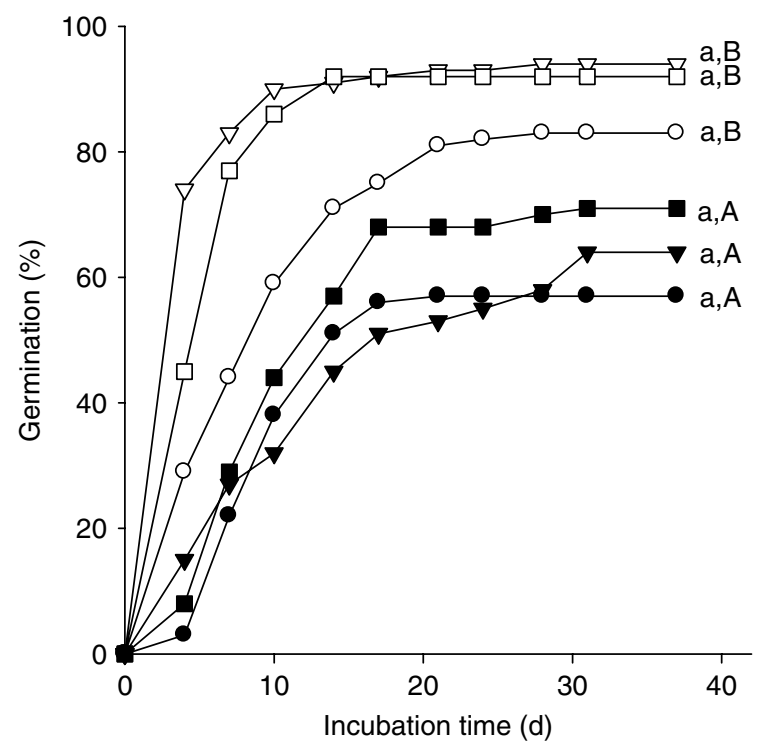

Figure 2. Germination of freshly matured embryos of Anthemis chrysantha from white (open symbols) and dark (closed symbols) achenes, at $15^{\circ} \mathrm{C}$ (circles), $20^{\circ} \mathrm{C}$ (triangles) and $12 / 20^{\circ} \mathrm{C}$ (squares) under light. 
Table 3. Mean germination time (MGT; days) of embryos from white and dark achenes of Anthemis chrysantha imbibed under light and different conditions of temperature

\begin{tabular}{lcc}
\hline Temperature $\left({ }^{\circ} \mathrm{C}\right)$ & White achenes & Dark achenes \\
\hline 15 & $9.44 \pm 0.36^{\mathrm{Ba}}$ & $10.29 \pm 0.58^{\mathrm{Aa}}$ \\
20 & $5.42 \pm 0.40^{\mathrm{Aa}}$ & $12.95 \pm 1.81^{\mathrm{Ab}}$ \\
$12 / 20$ & $6.28 \pm 0.16^{\mathrm{Aa}}$ & $11.11 \pm 0.28^{\mathrm{Ab}}$ \\
$F$ & 42.622 & 1.496 \\
$P$ & 0.006 & 0.275 \\
\hline
\end{tabular}

Means ( \pm standard error) within a column that have a different uppercase letter are significantly different from each other, and means within a row that have a different lowercase letter are significantly different from each other. $F$ and $P$ are the $F$-ratio value and the associated probability, respectively, obtained from the Tukey test at $95 \%$ confidence level.

\section{Anatomical characterization of achenes}

Both types of achenes were obconic (Figs 3A and 4A), glabrous, with ten ribs (Figs 3D and 4D) and usually scabrous. The ribs were almost equal and the ornamentation of the intercostal gaps was reticulate (Figs 3A and 4A). The anatomical study showed that the dark achene wall (pericarp) was generally thicker and stronger than the white achene wall (Figs 3E and $4 \mathrm{~F})$. The white achene pericarp was $16-40 \mu \mathrm{m}$ thick in the intercostal gaps and $50-80 \mu \mathrm{m}$ in the ribs (Fig. 3E). The exocarp consisted of flat epidermal cells with cellulosic walls that were not very thick. The cuticle of the outer tangential wall was $0.8-0.9 \mu \mathrm{m}$. Cell contents were very uniform, with a thick vacuole filling most of the cytosol and full of many microcrystals in suspension (asterisks in Figs 3C, 3F-3H). The middle layer (mesocarp) consisted of a single cell type - bulky cells that left some intercellular spaces (Figs 3E-3H). The primary wall was thin and cellulosic (dark blue when stained with toluidine blue), while the secondary wall was a little thicker (light blue when stained with toluidine blue) (Figs $3 \mathrm{G}$ and $3 \mathrm{H}$ ). The rib area contained mechanical tissue-fibres that were not very developed, mixed with some tracheids (Figs 3E and 3F). Only epidermal and parenchymal cells were found in intercostal gaps (arrowheads in Fig. 3E). A thin layer of cells formed the endocarp.

The dark achene pericarp had a thickness of 30$40 \mu \mathrm{m}$ in the intercostal gaps and of $85-115 \mu \mathrm{m}$ in the ribs (Figs $4 \mathrm{E}$ and $4 \mathrm{~F}$ ). The histology of dark achenes showed, from outside to inside, an exocarp of flat epidermal cells with cellulosic walls that were not very thick. The outer tangential wall had a thick cuticle $(1.5-2.5 \mu \mathrm{m})$. The cell content was very similar to that of white achenes, with a large vacuole that filled most of the cytosol and was full of many microcrystals in suspension (asterisks in Figs 4C, 4E and 4H). Below this area, an external mesocarp consisted of 2-3 very sclerotic cell layers of thick-walled, isodiametric cells with little lumen. The walls of these cells were very lignified (dyed red by double staining with safraninfast green and light blue with toluidine blue). There were few intercellular spaces, which made this layer a considerable and highly reinforced insulation. To the inside was the internal mesocarp of fibres arranged longitudinally in the direction of the achene (Figs $4 \mathrm{E}$ and $4 \mathrm{H}$ ). These fibres, especially abundant in ribs (Fig. 4F), were sclerenchyma fibres with very little cell lumen, occupied largely by cube-shaped crystals (arrowheads in Fig. 4H) located in rows along the cell. This internal mesocarp consisted of 8-10 layers of cells with no intercellular spaces. Among the fibres, some tracheids were distinguished toward the centre and were probably no longer functional in mature achenes. Finally, there was a thin layer of cells forming the endocarp.

\section{Discussion}

The present study revealed morphological differences in the achenes of $A$. chrysantha: basal dark achenes were significantly larger than upper white achenes in length, width, mass and pappus length. Dimorphism also occurs in many other species of Asteraceae (Imbert, 2002), although the morphological differences in $A$. chrysantha were not as distinct visually as for other species of the genus. In A. chia, for example, the achenes differ in the presence or absence of the wing (Imbert, 2002), and in A arvensis the achenes are clearly different in size (Ellis and Ilnicki, 1968 cited in Baskin and Baskin, 1998). However, the present anatomical study showed well-defined differences between the two achene morphs in A. chrysantha. The pericarp of dark achenes was thicker and stronger than that of white achenes. These differences in the fruit wall were most pronounced in the mesocarp. In dark achenes the mesocarp consisted of 2-3 layers of external sclerotic cells with very thick lignified walls, and 8-10 layers of internal cells with few intercellular spaces, making this layer a considerable and highly reinforced insulation. The mesocarp of the white achenes was much thinner than that of the dark achenes, and had intercellular spaces. These differences in the fruit wall may explain the different behaviour of the achenes in the water absorption experiment; the embryos of dark achenes absorbed almost no water after $36 \mathrm{~h}$ of imbibition while embryos of white achenes increased their mass by $72 \%$. However, $7 \mathrm{~d}$ after immersing the dark achenes in the dye solution, staining was observed in some areas of the embryos, although water penetrating after $14 \mathrm{~d}$ of imbibition only increased the embryonic mass by $34 \%$. Thus, dark achenes are not water impermeable but show very slow absorption rates, so that only when 

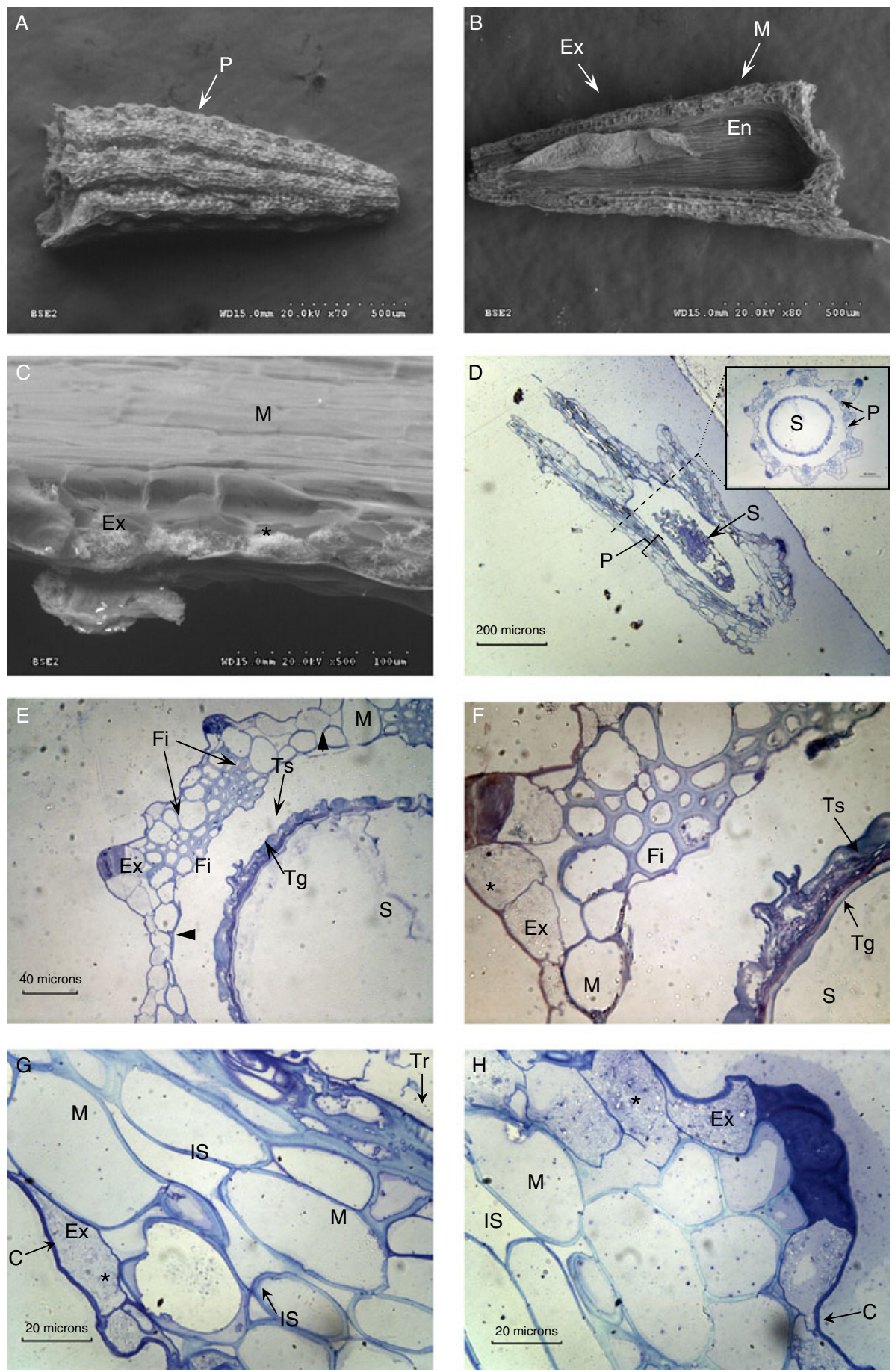

Figure 3. White achenes of Anthemis chrysantha. (A) Micrograph of a white achene observed by SEM. Note the external morphology of the pericarp, showing ribs and intercostal gaps. (B) Micrograph of a longitudinal section of an achene observed by SEM. (C) Micrograph of a longitudinal section of a white achene observed by SEM. Detail of pericarp showing the exocarp and mesocarp. Asterisks indicate microcrystals in suspension. (D) Micrograph of a longitudinal section of a white achene observed by light microscopy (LM). Insert: detail of a transverse section. Both sections stained with toluidine blue. Bars: $200 \mu \mathrm{m}$. (E) Micrograph of a transverse section stained with toluidine blue and observed by LM. Black arrowheads show the intercostal gaps. Bar: $40 \mu \mathrm{m}$. (F) Micrograph of a transverse section stained with toluidine blue (detail of a rib) and observed by LM. Asterisks show microcrystals in suspension. Bar: $20 \mu \mathrm{m}$. (G) Micrograph of a longitudinal section of pericarp stained with toluidine blue and observed by LM. Bar: $20 \mu \mathrm{m}$. (H) Micrograph of a longitudinal section of a rib stained with toluidine blue and observed by LM. Asterisks show microcrystals in suspension. Bar: $20 \mu \mathrm{m}$. Abbreviations: P, pericarp; Ex, exocarp; M, mesocarp; En, endocarp; Fi, fibres (sclerenchyma); S, seed; Ts, testa; Tg, tegmen; C, cuticle; IS, intercellular spaces; Tr, tracheids. (A colour version of this figure is available online at http://journals.cambridge.org/ssr). 

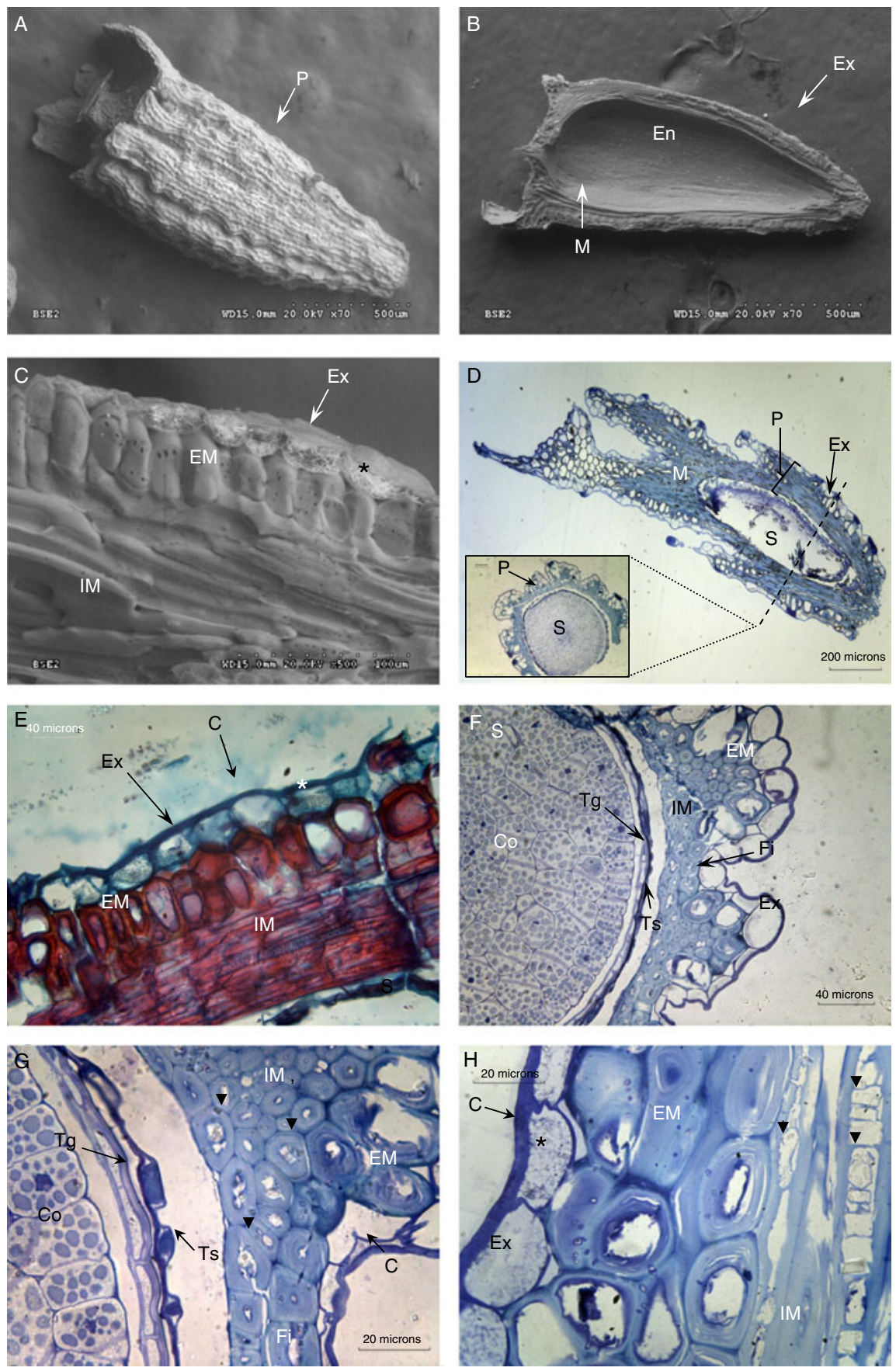

Figure 4. Dark achenes of Anthemis chrysantha. (A) Micrograph of a dark achene observed by SEM. Note the external morphology of pericarp showing ribs and intercostal gaps. (B) Micrograph of a longitudinal section of a dark achene observed by SEM. (C) Micrograph of a longitudinal section of dark achene observed by SEM. Detail of pericarp showing the exocarp, the external and the internal mesocarp. Asterisks indicate microcrystals in suspension. (D) Micrograph of a longitudinal section of a dark achene observed by light microscopy (LM). Insert: detail of a transverse section. Both sections stained with toluidine blue. Bars: $200 \mu \mathrm{m}$. (E) Micrograph of a longitudinal section of a dark achene stained with safranin-fast green and observed by light microscopy (LM). Asterisks indicate microcrystals in suspension. (F) Micrograph of a transverse section stained with toluidine blue and observed by LM. Note the external mesocarp and internal mesocarp in the ribs and intercostal gaps. Bar: $40 \mu \mathrm{m}$. (G) Micrograph of a transverse section stained with toluidine blue (detail) and observed by LM. Arrowheads show cube-shaped crystals. Bar: $20 \mu \mathrm{m}$. (H) Micrograph of a longitudinal section of pericarp stained with toluidine blue and observed by LM. Asterisks show microcrystals in suspension. Arrowheads show cube-shaped crystals located in rows along the cell. Bar: $20 \mu \mathrm{m}$. Abbreviations: $\mathrm{P}$, pericarp; Ex, exocarp; M, mesocarp; EM, external mesocarp; IM, internal mesocarp; En, endocarp; Fi, fibres (sclerenchyma); S, seed; Ts, testa; Tg, tegmen; C, cuticle; IS, intercellular spaces; Tr, tracheids; Co, cotyledon cells. (A colour version of this figure is available online at http://journals.cambridge.org/ssr). 
soil moisture conditions are profuse and sufficiently long, will water penetrate into the embryo. However, such conditions of soil saturation are rare in the habitat of $A$. chrysantha.

Morphological variations in the achenes may represent different dispersal ability (Greene and Johnson, 1989; Brändel, 2004). In A. chrysantha there are differences in the temporal dispersal pattern. More specifically, the white achenes located in the upper rows of the fruit head are dispersed some time before the basal dark achenes, as occurs in Bidens pilosa (Rocha, 1996), also of the Asteraceae. However, we have no data on the ability of spatial dispersal of the species, and future studies are needed to describe it in detail. In relation to this issue, and based on personal observations, we suggest that achene dispersal occurs by the action of raindrops falling on the fruit head (ombrohydrochory sensu Gutterman, 1990) and that the presence of bracts between achenes in the receptacle may play an important role in dispersal. The structure of the pappus may have little importance in the dispersal of this species, due to its short length which, together with the small size of the achenes, would not contribute to secondary dispersal, as in several species of Anthemis (Gutterman, 1990; Chehregani and Mahanfar, 2007). Moreover, variation in diaspore morphology is usually correlated with diverse patterns of dormancy and germination (Venable et al., 1987; Brändel, 2004; Sun et al., 2009). In the present study the morphological and anatomical differences between the two achene types of A. chrysantha were correlated with variations in their germinability. White achenes germinated to high percentages in many conditions, while basal dark achenes were strictly dormant and did not germinate under any of the test conditions. When fresh white achenes were incubated, the highest germination percentages were scored at $12 / 20^{\circ} \mathrm{C}$, both in light $(89 \pm 0.65 \%)$ and darkness $(72 \pm 1.85 \%)$, and the mean germination time was short $(5-7 \mathrm{~d})$. The final germination percentage at constant temperatures $\left(10-25^{\circ} \mathrm{C}\right)$ was lower than that at $12 / 20^{\circ} \mathrm{C}$, although it was also relatively high $(51-68 \%)$. When white achenes were stratified at $5^{\circ} \mathrm{C}$, the germination was very high $(90 \%)$. In general, cold stratification, warm stratification or dry storage did not improve the germination response of fresh achenes when temperature was optimal. However, dry storage or warm stratification improved germination at $15^{\circ} \mathrm{C}$. The fact that the white achenes germinated to high percentages at $12 / 20^{\circ} \mathrm{C}$, as well as $5^{\circ} \mathrm{C}$, suggests that achenes can germinate in both autumn and the coldest winter months (December-January). Field observations have shown that plants emerge from late September to March, a trait typical of a winter annual species. Alternating temperatures of $12 / 20^{\circ} \mathrm{C}$ are similar to the temperatures reached in south-eastern Spain in autumn, when $A$. chrysantha begins to germinate. Moreover, the ability to germinate over a range of temperatures is common in the Asteraceae (Baskin and Baskin, 1998; Schütz et al., 2002). In most temperature conditions, light appears to improve germination of fresh achenes. In many studies on germination models of plant groups coexisting in the same habitat, there are always some species that germinate better under light than in darkness (Schütz et al., 2002; Khan and Gulzar, 2003; Copete et al., 2009). This light-mediated germination mechanism favours germination of seeds located near the surface in areas of soil disturbance and prevents germination of seeds buried deeper in the soil, from which there is small chance of successful emergence of seedlings, especially for small-seeded species (Grime, 1979; Milberg et al., 2000). In the present study, the requirement for light was not absolute since germination of fresh achenes in darkness was considerable and was high at optimal temperature conditions $\left(12 / 20^{\circ} \mathrm{C}\right)$, contrary to most findings in small-seeded species (Grime, 1979; Milberg et al., 2000). Moreover, after warm stratification or dry storage the requirement for light was generally overcome. Therefore, the small fraction of achenes that will not germinate in darkness immediately after dispersal but will germinate after a stratification period, can create a temporary or short-term seed bank of white achenes.

In Asteraceae, absence of germination of some achene types can be due to the presence of either inhibitors in surrounding tissues (Beneke et al., 1993), thick pericarp (McEvoy, 1984; Tanowitz et al., 1987) or innate dormancy (Negbi and Tamari, 1963, as cited by Sun et al., 2009). The embryo germination test showed that embryos from fresh dark achenes reached significant germination percentages (57-71\%), although lower than those of embryos from fresh white achenes. Additionally, the scarification test showed that when the dark achenes are scarified at the basal end the germination percentage is similar $(72 \%)$ to that for completely excised embryos. However, when these were scarified on the apical end the germination reached $39 \%$. This indicates that the pericarp of the dark achenes is primarily a mechanical constraint to radicle emergence. The fact that the germination of excised embryos was not higher than that of the scarified achenes rules out the presence of inhibitors in the pericarp. Therefore, the causes of dormancy in the dark achenes should be sought in the thickness of their pericarp - physically impeding germination and hampering imbibition of water - as shown in other Asteraceae species (McEvoy, 1984; Tanowitz et al., 1987). The hypothesis of physiological dormancy can be rejected, since dark achenes did not improve their germination response after being subjected to wet cold and warm stratification (e.g. Baskin and Baskin, 1998, 2000, 2004). Moreover, taking into account that around $22 \%$ of 
dark achenes were non-viable, almost all of the viable achenes germinated when scarified at the basal end. This percentage of non-viable dark achenes can explain the differences in germination between dark and white achenes shown in Fig. 2.

In the Asteraceae, the difference in fruit mass is mainly due to differences in embryo size, but in a few species the difference is also due to pericarp structure (Beneke et al., 1992; Imbert et al., 1999). However, our study showed no difference in embryo mass between white and dark achenes (Table 1); therefore the greater mass of the dark achenes (Table 1) was due to the reinforced structure of their pericarp. Similar observations were made by Ellis and Ilnicki (1968) in $A$. arvensis, and they attributed the lower germination of larger achenes to pericarp hardening due to increased lignification. Thus, according to these authors and many others (Tanowitz et al., 1987; Mohamed-Yasseen et al., 1994; Sun et al., 2009), the thickness and structure of the pericarp plays an important role in germination, possibly due to differences in imbibition time, oxygen exchange and leakage of germination inhibitors. The embryos of the white achenes of $A$. chrysantha are not dormant, and the loosely structured pericarp does not prevent the passage of water.

Differences in dormancy levels of achenes from the same plant enable plants to spread their offspring in time (Venable, 1985). The results of our study suggest that the strategy and ecological adaptation of $A$. chrysantha are similar to those of most other heteromorphic species (Brändel, 2004; Sun et al., 2009), especially those in dry habitats (Gutterman, 1993). The partial dormancy of the white achene population and the pericarp-mediated dormancy of the dark achene population ensure that not all dispersed achenes germinate at the same time. Most white achenes germinate quickly or several months after a pulse of dispersal, especially if the latter is caused by rain. The delay of dispersal and germination of the dark achenes indicates the creation of a long-term soil seed-bank which ensures an available achene reserve on/in the soil of an unpredictable habitat, and thus increases the probability of persistence of an A. chrysantha population, as described by Sun et al. (2009) for Garhadiolus papposus of the Asteraceae. Moreover, delayed germination and seed storage in the soil increases the separation of genotypes in time and space (Baker, 1974), which may be particularly advantageous in the Asteraceae, where self-incompatibility is very frequent and would lead to a reduction of fertile progeny (Pandey, 1960). The results of the present study suggest that the presence of a large seed bank in the soil would play an important role in the population dynamics of $A$. chrysantha. Therefore, future studies should investigate the role of $A$. chrysantha seed banks in its habitats and the mechanism(s) of dormancy loss under natural conditions, as well as the mechanisms of achene dispersal in time and space.

\section{Acknowledgements}

This work was financed by the Consejería de Agricultura y Agua de la Comunidad Autónoma de la Región de Murcia and the Fundación Séneca de la Región de Murcia (Project 1186/PI/09).

\section{References}

Baker, G.A. (1974) The evolution of weeds. Annual Review of Ecology and Systematics 4, 1-24.

Baskin, J.M. and Baskin, C.C. (1998) Seeds. Ecology, biogeography, and evolution of dormancy and germination. San Diego, Academic Press.

Baskin, J.M. and Baskin, C.C. (2000) Seed germination ecology of Lesquerella lyrata Rollins (Brassicaceae), a federally threatened winter annual. Natural Areas Journal 20, 159-165.

Baskin, J.M. and Baskin, C.C. (2004) A classification system for seed dormancy. Seed Science Research 14, 1-16.

Beneke, K., von Teichman, I., van Rooyen, M.W. and Theron, G.K. (1992) Fruit polymorphism in ephemeral species of Naquamaland. I. Anatomic differences between polymorphic diaspores of two Dimorphotheca species. South African Journal of Botany 58, 448-455.

Beneke, K., van Rooyen, M.W., Theron, G.K. and van de Venter, H.A. (1993) Fruit polymorphism in ephemeral species of Naquamaland. III. Germination differences between polymorphic diaspores. Journal of Arid Environments 24, 333-344.

BORM (2003) Decreto $n^{\circ} 50 / 2003$, de 30 de mayo por el que se crea el Catálogo Regional de Flora Silvestre Protegida de la Región de Murcia. Boletín Oficial de la Región de Murcia 131, 11615-11624.

Brändel, M. (2004) Dormancy and germination of heteromorphic achenes of Bidens frondosa. Flora 199, 228-233.

Brenchley, J.L. and Probert, R.J. (1998) Seed germination responses to some environmental factors in the sea grass Zostera capricorni from eastern Australia. Aquatic Botany 62, 177-188.

Chehregani, A. and Mahanfar, N. (2007) Achene micromorphology of Anthemis (Asteraceae) and its allies in Iran with emphasis on systematics. International Journal of Agriculture E Biology 9, 486-488.

Copete, M.A., Herranz, J.M. and Ferrandis, P. (2009) Seed germination ecology of the endemic Iberian winter annuals Iberis pectinata and Ziziphora aragonensis. Seed Science Research 19, 155-169.

Ellis, J.F. and Ilnicki, R.D. (1968) Seed dormancy in corn chamomile. Weed Science 16, 111-113.

Greene, D.F. and Johnson, E.A. (1989) A model of wind dispersal of winged or plumed seeds. Ecology 70, 339-347.

Grime, J.P. (1979) Plant strategies and vegetation processes. New York, Wiley and Sons.

Gutterman, Y. (1990) Seed dispersal by rain (ombrohydrochory) in some of the flowering desert plants in the deserts of Israel and the Sinai peninsula. Mitteilungen aus dem Institut für Allgemeine Botanik Hamburg 23b, 841-852.

Gutterman, Y. (1993) Seed germination in desert plants. Adaptations of desert organisms. Berlin, Springer-Verlag.

Harper, J.L. (1977) Population biology of plants. London, UK, Academic Press. 
Imbert, E. (2002) Ecological consequences and ontogeny of seed heteromorphism. Perspectives in Plant Ecology, Evolution and Systematics 5, 13-36.

Imbert, E., Escarré, J. and Lepart, J. (1996) Achene dimorphism and among-population variation in Crepis sancta (Asteraceae). International Journal of Plant Sciences 157, 309-315.

Imbert, E., Escarré, J. and Lepart, J. (1999) Differentiation among populations for life history, morphology, head traits, and achene morph proportions in the heterocarpic species Crepis sancta (L.) Bornm. (Asteraceae). International Journal of Plant Sciences 160, 543-552.

Johansen, D.A. (1940) Plant microtechnique. New York, McGraw-Hill.

Khan, M.A. and Gulzar, S. (2003) Light, salinity, and temperature effects on the seed germination of perennial grasses. American Journal of Botany 90, 131-134.

Kreitschitz, A. and Vallés, J. (2007) Achene morphology and slime structure in some taxa of Artemisia L. and Neopallasia L. (Asteraceae). Flora 202, 570-580.

McEvoy, P.B. (1984) Dormancy and dispersal in dimorphic achenes of tansy ragwort, Senecio jacobaea L. (Compositae). Oecologia 61, 160-168.

Milberg, P., Andersson, L. and Thompson, K. (2000) Large-seeded species are less dependent on light for germination than small-seeded. Seed Science Research 10, 99-104.

Mohamed-Yasseen, Y., Barringer, S.A., Splittstoesser, W.A. and Costanza, S. (1994) The role of seed coat in seed viability. Botanical Review 60, 426-439.

Negbi, M. and Tamari, B. (1963) Germination of chlorophyllous and achlorophyllous seeds of Salsola volkensii and Aellenia autrani. Israel Journal of Botany 12, 124-135.

Nikolaeva, M.G. (1977) Factors controlling the seed dormancy pattern. pp. 51-74 in Khan, A.A. (Ed.) The physiology and biochemistry of seed dormancy and germination. New York, North-Holland Publishing Company.

Oberprieler, C. (2001) Phylogenetic relationships in Anthemis L. (Compositae, Anthemideae) based on nrDNA ITS sequence variation. Taxon 50, 745-762.

Pandey, K.K. (1960) Evolution of gametophyte and sporophyte systems of self-incompatibility in angiosperms. Evolution 14, 98-115.
Porras, R. and Muñoz, J.M. (2000) Achene heteromorphism in the cleistogamous species Centaurea melitensis. Acta Oecologica 21, 231-243.

Rashid, I., Reshi, Z., Allaie, R.R. and Wafai, B.A. (2007) Germination ecology of invasive alien Anthemis cotula helps it synchronise its successful recruitment with favourable habitat conditions. Annals of Applied Biology 150, 361-369.

Rocha, O.J. (1996) The effects of achene heteromorphism on the dispersal capacity of Bidens pilosa. International Journal of Plant Sciences 157, 316-322.

Ruzin, S. (1999) Plant microtechnique and microscopy. New York, Oxford University Press.

Sánchez, P., Carrión, M.Á. and Hernández, A. (2004) Anthemis chrysantha J. Gay. pp. 136-137 in Bañares, Á.; Blanca, G.; Güemes, J.; Moreno, J.C.; Ortiz, S. (Eds) Atlas y libro rojo de la flora vascular amenazada de España. Taxones prioritarios. Madrid, Dirección General de Conservación de la Naturaleza.

Schütz, W., Milberg, P. and Lamont, B.B. (2002) Seed dormancy, after-ripening and light requirements of four annual Asteraceae in south-western Australia. Annals of Botany 90, 707-714.

Silvertown, J.W. and Doust, J.L. (1993) Introduction to plant population biology. Oxford, Blackwell.

Spurr, A.R. (1969) A low-viscosity epoxy resin embedding medium for electron microscopy. Journal of Ultrastructure Research 26, 31-43.

Sun, H.Z., Lu, J.J., Tan, D.Y., Baskin, J.M. and Baskin, C.C. (2009) Dormancy and germination characteristics of the trimorphic achenes of Garhadiolus papposus (Asteraceae), an annual ephemeral from the Junggar Desert, China. South African Journal of Botany 75, 537-545.

Tanowitz, B.D., Salopek, P.F. and Mahall, B.E. (1987) Differential germination of ray and disc achenes in Hemizonia increscens (Asteraceae). American Journal of Botany 74, 303-312.

Tutin, T.G., Heywood, V.H., Burges, N.A., Moore, D.M., Valentine, D.H., Walters, S.M. and Webb, A. (1980) Flora Europaea. Vol. V. Cambridge, UK, Cambridge University Press.

Venable, D.L. (1985) The evolutionary ecology of seed heteromorphism. American Naturalist 126, 577-595.

Venable, D.L., Burquez, A., Corral, G., Morales, E. and Espinosa, F. (1987) The ecology of seed heteromorphism in Heterosperma pinnatum in central Mexico. Ecology 68, 65-76. 